\title{
Making sense of others: The use of biographical statements in Rosaura a las Diez
}

Teófilo Espada-Brignoni *

Xavier University School of Medicine, Aruba

Corresponding Author: Teófilo Espada-Brignoni, E-mail: tespadaphd@xusom.com

\section{ARTICLE INFO}

Article history

Received: December 08, 2017

Accepted: January 23, 2018

Published: February 28, 2018

Volume: 9 Issue: 1

Advance access: January 2018

Conflicts of interest: None

Funding: None

Key words:

Denevi,

Discourse,

Foucault,

Goffman,

Biography,

Medicine,

Psychology

\begin{abstract}
Marco Denevi's Rosaura a las Diez is a novel that explores the complex relationships between law, science, and everyday life. These fields of human experience play a fundamental role in the construction of the social categories and biographical statements individuals use to understand their world. This article draws from the works of Michel Foucault and Erving Goffman to analyse the way in which Denevi explores individuals making sense of themselves and others.
\end{abstract}

\section{INTRODUCTION}

Human life is embedded in stories. We are products, as well as producers, of tales and fables that fill the world with meaning. Members of particular societies make up stories to explain their world and to give credence to what they believe. Individuals, groups, communities, or countries share these tales, providing a general framework to make sense of their experiences. Some stories may, to differing degrees, support or problematise the state of affairs, such as social discourse and narrative conventions. Furthermore, as reading Marco Denevi's novel Rosaura a las Diez shows, human reality is often a set of stories based on stories we hear and analysed through stories we know. These tales and their complex relationships allow researchers in the social sciences and humanities to analyse the way in which a particular society constructs certain explanations about human life or critiques other explanations. As Alan C. Elms recognises, academics also tell stories and writers also research (241242). Analysing literature, not only as an object but also as a socio-psycho-philosophical examination of life, allows us to explore how groups and individuals make sense of their world. Furthermore, socially accepted narratives about kinds of individuals construct both their social identities and their biographies.

In this article, I analyse Marco Denevi's award-winning 1955 novel Rosaura a las Diez not only as a work of fiction but also as a socio-psychological thesis of how individuals make sense of their world through the discourses available to them in a particular society and the groups they belong to. According to Michel Foucault, discourses are groups of statements characterised by how they construct their objects (Archaeology 107, 115). Furthermore, "discourses promote ways of framing the self and human action in relation to the self and others" (Espada-Brignoni \& Ruiz-Alfaro 55). Discourses also exist in relation to "non-discoursive areas" (Jansen 110) such as the institutions in which they are embedded. In a way, stories are a blend of creative effort and examined or unexamined social discourses. Individuals construct images of the world by drawing not only from personal experience but from the discourses a particular society and the groups they belong to hold as true. In this article, I analyse biographical statements in Rosaura a las Diez and how they are promoted or supported by social institutions within the novel's universe. In Rosaura a las Diez, characters make the stories of others by developing 
biographical statements using the discourses to which they have access.

Denevi's novel, published before books such as Erving Goffman's Stigma and Michel Foucault's Discipline and Punish, anticipates and interacts with the social theory of the second half of the twentieth century. In a way, Denevi's novel constructs a psycho-sociological map of how notions about the self are used to understand and stigmatise others within a particular society. In this article, Denevi's novel is both an object of study and a literary contribution to the study of discourses and how they shape the way members of a particular society make sense of their world. As a social psychologist, I'm particularly interested in how discourses mediate relationships between individuals, and for this Denevi's novel provides rich material. He examines how humans construct ideas about others and which social institutions play an integral part in making the stories of oneself and others. My specific research question asks how Rosaura a las Diez, as a case study, analyses the relationships between discourse, institutions, and the production of biographical statements. Furthermore, biographical statements are related to notions about kinds of beings in the modern world, where fields of experience and knowledge such as everyday life, medicine, psychology, and law have been accepted as bearers of truth which individuals use to understand others.

In the next section, I describe Denevi's novel as both a crime novel and a psycho-sociological work. Then, I deal with concepts related to the discursive construction of the biographies of others and how this relates to Rosaura a las Diez and social theory. Next, I analyse how the novel uses biographical statements, how such statements construct categories of being, and the fields of knowledge and experience that promote and support specific kinds of biographical statements. These fields are more or less related to the particular institutions Denevi identifies as products and producers of the categories that mediate the relationships between one person and others.

\section{CRIME NOVELS AND ROSAURA A LAS DIEZ}

Marco Denevi was born in Sáenz Peña, a province of Buenos Aires, Argentina, in 1922 and died in Buenos Aires in 1998. According to David Lagmanovich, Denevi is one of Argentina's most important narrators (69). His first novel, Rosaura a las Diez, often described as a crime novel (Lafforgue and Rivera 22), earned him the Kraft award, and thanks to the popularity of the work, Mario Soffici turned it into a film in 1958 (Laforgue and Rivera 22; Revel Grove 11). After the novel's translation into English, Alexander Coleman wrote a brief review of the work for the New York Times in 1964. Coleman also classified Denevi's novel as a crime novel and argued that reading it was a "devious but engrossing experience" (47).

Classical crime fiction employs brilliant amateurs who solve crimes through scientific reasoning. However, since its beginnings in the last decades of the nineteenth century, one of the features of Argentinian crime fiction has been the lack of reliability of its narrators (Setton 259). Denevi's novel, however, is a work of crime fiction, a sample of life-writing, and a social document revealing how individuals make sense of their lives. Lafforgue and Rivera include Rosaura a las Diez as part of the history of Argentinian crime novels. Ivonne Revel Grove also frames Rosaura a las Diez as a crime novel (15) and claims Denevi's other novels, at least those published before her book, as crime novels or suspense (66). Book reviews in the United States describe Denevi's novel as crime fiction (Coleman 46) while recognising that the work does not completely fit within the genre (Lewald 128). Some have compared Denevi to Wilkie Collins because of his reconstruction of the crime from multiple perspectives (Abadie 62; Lewald 128).

Denevi's novel is neither biography, autobiography, nor memoir; however, it blends some of the qualities of such genres similarly to the way people do in their everyday lives. His characters' accounts of events alternate between autobiography, biography, and memoir. They speak about what they see in their own lives and imagine in the lives of others. One of the features of classical crime fiction is precisely that use of "points of view" since "no observation exists without an observer" (Todorov 46). Denevi approaches this device not only as a crime novel convention but also from a sociological and psychological standpoint. Through points of view, Denevi explores how individuals use popular everyday life discourse, represented primarily by Milagros, and law and medicine, featured in David's narration.

Denevi's narrators also reproduce the oral traits of their social and cultural backgrounds (Abadie 62). He imagines and depicts the complex psychological and social profiles of his characters, both as psychological entities and as narrators. As David Lagmanovich argues, in Denevi, the reason for saying something is just as important, or perhaps more, than what or how the narrator speaks (73). In Rosaura a las Diez, Denevi analyses and problematises the why, how, and what of the narration. The why is of particular interest since the theme featured throughout the novel is the construction of biographical statements. If we seek to explain why narrators say what they say, we might answer that it is because they have constructed biographies about the two protagonists, Camilo and Rosaura.

Rosaura a las Diez has five chapters, each written in a different manner. The first chapter is a first-person narration by Milagros Ramoneda, the owner of La Madrileña, a lodging establishment. Her chapter consumes a little more than half the book and is a linear narration from the time she met Camilo Canegato to the moment she found out about his arrest. David Réguel, a law student and resident of La Madrileña, narrates the second chapter. In the 1993 edition of Centro Editor de América Latina, David's chapter is a single 36-page paragraph. Réguel attempts to explain why Camilo is guilty using penal and medical knowledge. The third chapter is a conversation between inspector Julián Baigorri and Camilo. The fourth chapter is a fragment of Eufrasia Morales' declaration to the police, and the fifth chapter is a fragment of a letter written by the woman everyone was calling "Rosaura."

Each narrator tells the story from his or her own subjective perspective. Camilo arrives at La Madrileña twelve 
years before the events in question, seeking a place to live after his father's death. To earn money, he restores paintings and paints portraits over enlarged photographs in a style selected by his client. After twelve years pass, Camilo begins to receive perfumed letters from a woman named Rosaura. The mystery grows because Camilo never mentions the letters until one is "accidently" addressed to La Madrileña and not to Camilo. Although the letter is supposedly for Camilo, Milagros, her daughters, and Eufrasia are curious about its contents and decide to open the envelope. The novel reveals that Milagros and her daughters had already read the previous letters while Camilo was at work (Denevi 26). Milagros and her three daughters imagine Rosaura as an old woman or one with an imperfection. According to her daughters, the letters are romantic and anachronistic (Denevi 29).

A woman, who appears identical to a small portrait Camilo made of Rosaura from memory, visits La Madrileña asking if Camilo Canegato lives there (Denevi 80). Almost everyone except Camilo greets her. She lives for a few days in La Madrileña while Milagros arranges their marriage. After the wedding, they go to a hotel. David Réguel, however, who suspects Camilo of possible wrongdoing and is infatuated with Rosaura, follows them and sees Camilo fleeing their hotel (Denevi 136). Réguel stops Camilo and, fearing the worst, calls the police. When the police enter the room, they find Rosaura's body. Rosaura, however, was not the victim's real name; the name in her documents is actually Marta Córrega. The final chapter reveals that Rosaura's name, whether real or another alias, is María Correa. She became Marta Córrega when Sarkis Abulaf, the owner of the hotel where she died, gave her a false identity (Denevi 182). The novel unfolds gradually through the opaque narration of each character. Their narrations not only reveal the story little by little but allow us to study how individuals make up stories about others. This is not because they are lying, but because they are using the personal experience and social discourses available to them.

\section{KINDS OF BEINGS AND BIOGRAPHICAL CARTOGRAPHIES}

Each narrator, whether in Denevi's world or ours, makes biographical statements using his/her own personal experience and social discourses to make sense of others. In his essay "Between Michel Foucault and Erving Goffman", Ian Hacking argues that the two authors can be used complementarily because they both study the ways in which particular societies construct and use categories of being (Hacking 277-278). In modern Western society, notions of kinds of beings are associated with biographical statements. Such statements may be about another or about oneself. As Judith Butler writes, "The very terms by which we give an account, by which we make ourselves intelligible to ourselves and to others, are not of our making. They are social in character" (21). Society and its institutions supply the general biographical cartographies of human life, the sketches individuals use to make attributions about others. In their works, Foucault and Goffman analyse the production of social categories, pro- viding the conceptual tools to understand such biographical cartographies and how they are employed.

As Goffman argues, "'Society establishes the means of categorising persons and the complement of attributes felt to be ordinary and natural for each member of these categories. Social settings establish the categories of persons likely to be encountered there" (Stigma 2). Society naturalises these categories through the stereotypes, discourses, and institutions of everyday life. Society also outlines kinds of people through what Foucault calls mode of subjection. According to Foucault, the mode of subjection is "the way in which the individual establishes his relation to the rule and recognizes himself as obliged to put it into practice" (Use of Pleasure 27). This is the positive side of subjection; the promotion of a kind of being that follows the moral guidelines of his culture. If there is a quality of Rosaura a las Diez worth noting, it is precisely how through the novel Denevi portrays and analyses the way lives are weighted against preconceived ideas individuals hold about "kinds" of people.

Considering subjection a discursive phenomenon, part of the group of statements that define persons and objects in a particular society, society also defines the kinds of beings unable to fit within its standards. Both the "normal" individual and those whose identities are spoiled can be the subject of biographical statements. As Goffman argues, "When an individual leaves a community after residing there for some years, he leaves a personal identification behind, often with a well-rounded biography attached, including assumptions as to how he is likely to "end up"' (Stigma 78). Some individuals might even consider their biography of a person more accurate than others'. Biographies deal with both the past and the future because they analyse past events and speculate about what someone might do in a specific future situation.

According to Philippe Lejeune (23), when someone writes the biography of another individual, the writer uses the real individual who is the object of the biography as a model. Rosaura a las Diez problematises this notion since Rosaura is both real and imaginary. At the level of conversation, discourse, and interaction between the characters, Rosaura is real. She affects others and is affected by them. However, there is no person by that name. There is, however, a person who was the victim of an actual crime, but her name is not actually Rosaura. They are, of course, the same person. Camilo, on the other hand, is a real person within the novel, but there are several sketches of him depending on the point of view of the narrator. The narrators' physical-biological reality of these characters is relatively insignificant, for it is their discursive biographical reality that is at stake. Whether Camilo exists and Rosaura does not is irrelevant. What is significant is that both are subject to the biographies others create about them. Thus, the model for such biographies is not a "real" individual, but the categories of being available in society to understand and make sense of others, constructed through fields such as everyday life (including popular culture), law, and medicine. 


\section{MAKING BIOGRAPHIES}

As Maynes, Pierce, and Laslett argue, human life is "constructed through self-narratives, culturally shaped and interactive forms that yield operative self-understanding that evolve over time" (42). The same discursive resources available to understand one's own life can also be employed to make sense of others' lives, and vice versa. Rosaura a las Diez explores the role of making biographical statements within interpersonal relationships as well as within the fields mentioned above, providing possibilities for drawing clues about the lives of others. Furthermore, a certain degree of commensurability in the biographies of interlocutors is necessary to understand the others' lives and to make one's life understood. In her attempt to assess her situation, María Correa needs to know what Camilo told the residents of La Madrileña about Rosaura. Rosaura asks David Réguel, “Qué les contó Camilo de mi?” (Denevi 128). David tells her what they knew about her, for which she thanks him (Denevi 129). A few days later, during another conversation between them, Réguel recites, without quoting, romantic verses by Argentinian poet Leopoldo Lugones, and asks Rosaura if she really likes Camilo. Instead of answering, she asks about his life to change the subject of the conversation. Her request moves David Réguel deeply, and he expresses a cathartic need to talk about his own life:

Hablé de cosas que nunca había dicho a nadie. Cosas que uno lleva adentro. No sé por qué, pero tenía deseos de desahogarme, de confiarme a alguien, de encontrar en la oscuridad una mano que apretase la mía, oír una voz que me dijese: te comprendo (Denevi 129).

In these sentences, David expresses his need for a meaningful romantic relationship based on sharing one's biography. This is perhaps the character's most vulnerable moment in the novel, when he tells Rosaura secrets that are not shared with either the police or the reader. Many of David's comments on the case are intellectualised brainstorms referencing law, medicine, and highbrow culture. In a psychoanalytic manner, his catharsis reveals his romantic desires and his vulnerability. In a way, Camilo's own narration of the story also serves as catharsis and self-discovery. By confessing that he invented Rosaura, Camilo expresses his desire for love. He even thinks he likes music more than painting, since he became a painter because his father taught him the trade when he was twelve years old (Denevi 152).

Certain traits, events, or behaviours are used to infer the biographies of others. When Camilo tells Milagros his father died of a stroke, she concludes he was an alcoholic. She justifies this statement about Camilo's father using her own experience with her husband, who is briefly mentioned and depicted as an alcoholic who died from stroke. Medicine and personal experience reinforce each aspect of her analysis of Camilo's father. Milagros restates this theme in a comical conversation. When she asks Camilo what he and his father ate, he says his father only liked one thing. Milagros interrupts him with, "Si, ya sé" (Denevi 15). Camilo noted that they always ate pasta, but she inferred that he meant alcohol. Likewise, Inspector Baigorri offered Camilo a cigarette, be- lieving he was a smoker only because his fingers were yellow. However, according to Camilo, this was not the result of smoking, but of using certain chemicals to restore paintings. These are examples of behavioural and physical stigmas (two of the three kinds of stigmas Goffman identifies) where "a trait that can obtrude itself upon attention and turn those of us whom he meets away from him" (Goffman Stigma 5).

In Rosaura a las Diez, Denevi investigates the functions of biography within interpersonal relationships. Often, individuals walk into situations where others have previously talked about them. Thus, the newcomers must face the biographies created by the original inhabitants of the situation based on what those persons believe. For example, María Correa, the newcomer, does not know why the inhabitants of La Madrileña call her Rosaura and finds their treatment of her startling. Goffman writes, "The individual who is known about by others may or may not know that he is known about by them" (Stigma 66). Visual stigmas (the colour of Camilo's fingers), diseases (Camilo's father's stroke), and scented letters are also vehicles to imagine the past of an individual. Interlocutors use their own past experiences to deduce the biographies of others. Denevi constructs the autobiographical act as a cathartic confession of the self wherein an individual becomes vulnerable to others. For example, following a psychoanalytical hypothesis, Réguel intellectualises life to deal with reality and presents himself as a strong-willed individual; however, by narrating his life to Rosaura, he becomes and feels vulnerable. Furthermore, it seems Camilo discovers personal traits through his confession to the police.

\section{KINDS OF BEING IN ROSAURA A LAS DIEZ}

Rosaura a las Diez explores several kinds of being within everyday life. Everyday life is a fundamental field in the constitution of subjectivity, promoting ways of understanding the self and the other. Additionally, other fields, such as law and medicine, influence everyday life. These disciplines produce discourse that can promote, problematise, or justify the general ideas employed in everyday life. Everyday notions about reality shape, and are shaped by, both popular and highbrow culture. Current scholarship critiques the opposition between so-called lowbrow and highbrow culture regarding popular works of fiction in literary studies. As Peter Swirski argues, "Popular literature expresses and reflects the aesthetic and social values of its readers" (6). The multiple stories that make up his/her worldview mediate an individual's engagement with reality. Life provides the basis for literature, television, theatre, and music, which in turn provide the stories that allow engagement with life. Denevi posits that individuals use both popular culture and so-called serious literature to understand their world.

In Rosaura a las Diez, both low and highbrow culture provide discursive resources to understand the lives of others and imagine their pasts. The entire novel blurs the lines between low and highbrow by referencing multiple sources from Argentina and Europe, and imagines narrators on a continuum. Milagros is closer to popular culture, David constructs himself as more sophisticated, and Camilo might 
be somewhere in the middle. Milagros' daughters, although they are not narrators and the reader only knows about them through others, appear to be cultured and knowledgeable. However, David Réguel argues against this perception, imagining Rosaura as the only cultured woman in La Madrileña.

While Denevi's novel explores several kinds of beings, two are objects of debate. The novel features teachers, students, retirees, and maids, among others, but the general categories used to evaluate and make sense of other's lives are artists and characters. These categories are embedded in modes of subjection, general ideas about kinds of individuals, negotiated with general notions and expectations of what it means to be a normal, responsible, and moral adult. In other words, the narrators' critique of the Bohemian lifestyle and weak character as well as their construction of the others' biographies reveal socially constructed expectations about the self. Narrators deal simultaneously with social discourse and individual experience. While Milagros might criticise Camilo's profession, her maternal feelings towards him and, during their first meeting, his ability to pay for his room play an integral role in her evaluation of the protagonist.

Milagros depicts artists as dangerous individuals in the same category as students and other adherents to the Bohemian lifestyle. In Milagros's account, students and artists are unreliable. Travelling actors wear a red flag that makes them easy to identify. Actors, "llevaban la luz roja encendida al frente y era posible esquivarlos a tiempo y desde lejos" (Denevi 5-6). Although her first impression of them was often positive, her experience warned her against them. When Camilo tells her he is a painter, she asks if he paints houses. For Milagros, painting houses is an "honrado oficio" (Denevi 7), a noble job. On the other hand, in Camilo's fantasy, Rosaura's father would never allow her to date a painter (Denevi 69). Rosaura's father condemned Camilo's profession and its Bohemian identity. However, Camilo represents no stereotype of the Bohemian lifestyle; even his wardrobe gave Milagros a sense of security since he resembled a notary or an out-of-date marquis more than he did an artist (Denevi 6).

Milagros depicts "damiselas" in a similar manner to artists. While she criticises artists for their financial lapses, Milagros condemns "damiselas" for what she speculates are immoral behaviours. According to Milagros, "Se acuestan al alba y se levantan a la hora del almuerzo" (Denevi 5). Single men also arouse suspicion, but Milagros prefers not to talk about them. Throughout the novel, singlehood represents a defect; however, widowhood does not because it is involuntary. For Milagros, fiscal responsibility and conventional morality are positive signs. She also justifies her adherence to strict rules, except in times of national economic hardship, to the home-like atmosphere she promotes and the safety of her three daughters. Using popular knowledge and stereotypes, Milagros stigmatises individuals who fail or refuse to live within conventional morals.

A second kind of being emerges throughout the novel: the weak individual. As Sonia Mattalia suggests, one of the precursors of crime novels is the psychological analysis of character (21). Rosaura a las Diez negotiates various definitions of weak character throughout the text. According to
Revel Grove, many of Denevi's short stories deal with individuals who lack willpower or character, inadequate subjects unable to fill the socially imposed imperatives of adulthood and/or their gender. One of the words Milagros uses to describe Camilo's weaknesses is "hombrecito" which translates to "little man." Both Milagros and David depict Camilo as a weak individual. For Milagros, hombrecitos are pitiful beings who must be encouraged to act. For David, hombrecitos are frustrated and dangerous individuals; he uses law and medicine to justify his negative declaration about the protagonist. Furthermore, Camilo himself internalises a description of individuals as weak characters. These characters strategically use the same stigma through their discourses of (p) reference to argue whether Camilo was capable or incapable of killing Rosaura.

Milagros expected immoral behaviour from artists; however, as she found out, he seemed an innocent childlike person who had no interest in the Bohemian lifestyle. She even calls Camilo "un pan de Dios" (Denevi 16), a popular Latin American expression that literally translates as "bread from God" and depicts humble, innocent, and kind person. Milagros adds, "Su timidez, especialmente con las mujeres, era casi una enfermedad" (Denevi 16). In this sentence, Milagros claims Camilo's shyness around women is like a disease. According to Milagros, an actress nicknamed La Chelo used Camilo's shyness to her advantage and took money from him, which she never returned. The initial story with María Correa, who later became Rosaura, was similar. Someone María calls her aunt took advantage of Camilo's shyness and set him up with María, who took his money in exchange for sexual favours. Readers might infer Camilo and La Chelo had a sexual affair. However, Milagros does not suggest such ideas to the police. Furthermore, any relationship between Camilo and La Chelo would need some degree of participation from both; however, framing La Chelo as the perpetrator and Camilo as the victim fits Milagros's worldview. Bohemian artists are again troublemakers, and Camilo is a vulnerable victim. Furthermore, Milagros once believed Rosaura was taking advantage of him (Denevi 24).

When the postman delivers Rosaura's first letter, Milagros believes another one of the male residents is the recipient. Even knowing Camilo is the recipient, two of the daughters, Enilde and Matilde, believe the letters are not amorous, arguing he is not that kind of man (Denevi 24). Milagros, however, argues all men are the same way, thus classifying the relationship as immoral. She feels better when Camilo tells her about Rosaura. Through their conversation, he explains that he and Rosaura will wait for marriage before consummating their relationship. David also problematises Camilo's masculinity for what he notes are perverse desires born out of repression and his inability to find a sexual partner under normal circumstances (Denevi 112). These characters give different accounts of Camilo's masculinity. From absent, to universal male immoral desires, to perverse, they negatively characterise the nature of his masculinity using what they believe they know about him. Camilo justifies fabricating his story with Rosaura to construct another persona. He wishes to be an object of de- 
sire (Denevi 158), and in inventing Rosaura, he attempts to reinvent himself.

The relationship between the categorisation of Camilo and his reactions resembles the study of looping effects in social theory (Hacking 298-299). Camilo reacts against the ideas and biographies others make of him as a weak asexual male. Camilo argues, "Yo era el ayo sin sexo y sin instintos, delante del cual podían hablar de sí mismas y de los hombres como si estuviesen solas" (Denevi 158). He feels others consider him an asexual being without desires. However, his reaction against such classification actually reinforces the way most characters already view him. Even when they have evidence that the relationship between Camilo and Rosaura is romantic, they imagine several faults. He reacts again by "painting" Rosaura and showing them a beautiful woman can love him (Denevi 161). However, this also backfires because, Enilde joked, Camilo painted Rosaura "con la óptica engañosa del amor" (Denevi 62). In other words, Enilde claimed, Rosaura could be beautiful in a painting but not in real life because he painted her subjectively, making her more beautiful on the canvas.

Once Milagros believes Camilo's relationship with Rosaura is within the boundaries of her view of morality, she imagines Camilo's behaviours throughout his story with Rosaura. Milagros interprets Camilo's account of their relationship through her ideas about his shyness and weakness. Milagros, perhaps inadvertently, imagines how Camilo reacts, giving more credence to her own interpretation than to his actual account. She imagines how, on his way to Rosaura's house to restore the painting, he sat in an uncomfortable position without daring to move (Denevi 45). According to Camilo, the first time he saw Rosaura, they stood in silence, and after a few minutes he decided to talk to her. Milagros, however, argues it was a possible half an hour (Denevi 51). Afterwards, Milagros criticises Camilo in front of Rosaura, since due to his timidity, cowardice, and principles, he was not man enough to kidnap Rosaura (Denevi 85). After listening to Camilo's stories, Milagros either fills in the blanks or corrects what she believes are inaccurate depictions of the story.

Most of these events actually occurred, but Milagros's interpretation of Camilo's story serves as one of the main arguments of the novel. Camilo's work as a restoration specialist thematises this idea within the novel. Even with the police, with whom he seems most forthcoming, Camilo does not explain the whole truth behind his trade. While he admits painting expanded photographs to create portraits, he misleads the police by arguing that he painted Rosaura using only his imagination. However, truthfully, Camilo painted Rosaura from a picture he had of María Correa. Rosaura, then, is in everyone's eyes a picture of another picture painted by Camilo from a medley of his desires, his imagination, and an old photograph. In a way, the readers themselves are painting pictures on top of those pictures, further obscuring the possibility of knowing the characters. Even in the interaction between novel and reader, Denevi thematises how human encounters are mediated by social discourses.
Throughout their interactions with the detectives, both David and Camilo feel the need to explain their own characters. David seems affected by Rosaura's death as he speaks to the detective:

No soy un flojo, pero me parece que cualquiera en mi lugar, ¿no es cierto? Porque cuando pienso que yo, casi sin quererlo, bueno, sin quererlo no, pero, en fin, arrastrado por la fuerza de las circunstancias, llegando más allá de lo que me propuse, preterintencionalmente, ésa es la palabra, ¿qué decía? (Denevi 102)

In these sentences, David explains his emotional state. $\mathrm{He}$ argues that while he is not a weak individual, anyone in his circumstances would be in the same state. By arguing that anyone would react the same way he did, David not only explains his reactions but attempts to avoid shame (Goffman Presentation 12), to maintain his credibility, masculinity, and intellectual superiority in his exchange with the police. David also tries to specify the degree of his relationship to the events. In the same sentence, he moves from claiming his role was unintentional to admitting he might have had a degree of participation in the story, that the circumstances involved him more than he had originally expected. This fragment ends, however, with David asking, "What was I saying?" and losing his line of thought several times.

In the fragment quoted above, he intellectualises his relationship to Camilo and Rosaura's drama, forgetting that he wanted to justify his mental state. The events in question and the presence of feelings for the victim would sadden or upset most people, whether weak or strong. However, David supports discourse and intuition that stigmatise weak individuals. His depiction of Camilo has references to judicial and medical discourse that he accepts almost blindly while criticising Milagros's account and evaluation of Camilo's character. David quotes medicine and law while attempting to prove he is not, within that discourse, a weak individual.

As Goffman argues, through socialisation-specifically, what he calls the moral career - an individual "learns and incorporates the standpoint of the normal, acquiring thereby the identity beliefs of the wider society and a general idea of what it would be like to possess a particular stigma" (Stigma 32). Subjects are not passive beings. They accept or problematise, in varying degrees, how official discourse depicts them. Considering Camilo as a stigmatised individual implies the possibility that he internalised discourse about weak individuals.

Camilo does construct himself as a weak and anxious individual and as a possible object of psychoanalytic inquiry. For example, Camilo tells the police that if he wrote a book about his dreams, psychoanalysts would profit from it: "Yo podría escribir un libro, con todos mis sueños, y los psicoanalistas harían su agosto" (Denevi 152). In Argentina, psychoanalytic theory dominated the psychological and psychiatric. Psychoanalysis was also an important cultural force popularised by several kinds of publications describing Freud's theory to the general public (Vezzetti 183). Through his conversation with Julián Baigorri, Camilo is aware of their positions within psychological and everyday life stereotypes. "Usted es un hombre de acción. Yo soy un hombre 
sin carácter, como dice la señora Milagros" (Denevi 153). According to Camilo, Baigorri is a strong person but, quoting Milagros, he adds that he lacks character. Furthermore, Camilo considers himself a weak person; he lives "inhibido" (Denevi 150). On this occasion, he also quotes Milagros, who represents society at large: "no tengo carácter, como dice la señora Milagros" (Denevi 150). Not only does Camilo internalizeise the categories used to describe him, he also accepts the attributes associated with such stigmas, acknowledging he is a repressed and frustrated person.

As Goffman suggests, the presence of those considered "normal," or who are at least in most accordance with society's expectations, reinforces the opposite. For Camilo and David, the detectives represent "normality," which reinforces the individuals' opinions of themselves. They are compelled to account for the samples of their character to which the detectives have access. Their interpretations of the weak male reveal a modern subjection where individuals value strength of character, willpower, and resilience. Denevi's characters negatively frame the vulnerability of the self as acceptable only within romantic relationships. Maternal relationships may allow a degree of vulnerability for the individual positioned as son or daughter, but only for those within that relationship. Only Milagros frames her relationship with Camilo as maternal, and she is the only narrator who describes his vulnerability in a pitiful manner while at the same time forcing him to overcome it by fighting Rosaura's father.

Society promotes certain kinds of beings, providing the general framework to understand the self and make biographies of others. In Rosaura a las Diez, Denevi explores the consequences of being one of the kinds of individuals who fail to adjust to society's expectations. The ideas examined in this section deal with general social stereotypes that spring from society at large. However, as I discuss in the next section, law and medicine also construct and shape social reality.

\section{LAW AND MEDICINE}

In Western society networks between law, medicine, science, and other fields related to power and knowledge are far from simple. They emerge from the same episteme. According to Foucault, "The exercise of power perpetually creates knowledge and, conversely, knowledge constantly induces effects of power" ("Prison Talk" 52). These relationships are complex and diverse. For example, while the state might elaborate policies related to scientific knowledge, scientists do not want to be a guilty party in destroying the world (Medawar 12-13). Socially upheld values, stereotypes, and conventional morality can guide scientific research and theory (Keller 13, 53). However, at other times, science irreversibly problematizes worldviews.

Psychology, psychoanalysis, medicine, and law are disciplines that define humans in both positive and negative ways. In other words, they promote kinds of beings and play a role in the stigmatisation of others. Positive and negative are only descriptive terms referring to the positioning of some identities in relation to others. The disciplines mentioned play an integral role in explaining human beings, including how they are controlled, imagined, and known. As a law student, David Réguel represents, almost as much as the police, the field of power and its relationship to knowledge. In a way, David also partially represents the amateur detective who, through his reasoning, attempts to make sense of the case. He even begins his narration by claiming that police have only external facts and lack knowledge about the motivation behind the crime. David compares himself to Buddha, arguing he is the one who knows the truth of the crime (Denevi 102).

The question is, what kind of truth does David claim to possess? His knowledge derives from psychoanalytical and judicial documents. However, he discards the works of jurist Francesco Carrara, arguing he proposes crimes can exist without motive (Denevi 102). In biographical and autobiographical societies like ours, Carrara's notion does not fit well. Carrara also opposed projects such as preventive imprisonment, arguing vague suspicions are not sufficient to imprison someone (Álvarez 200). Psychological knowledge and police work are not separate; from its beginnings, modern psychiatry was part of the general discourse and practice of social control (Foucault, "Enfermement" 333). Law and psychological knowledge promote a biographical conception of human beings that reduces individuals to a single category. Both so-called normal and stigmatised individuals use such discourse. Camilo himself had several over-the-counter remedies for what he described to Milagros as head fatigue from dreaming too much (Denevi 14).

As Foucault writes in Discipline and Punish, "In becoming the target for new mechanisms of power, the body is offered up to new forms of knowledge" (155). David depicts Camilo as a corruptor, a dangerous individual whose physiology and psychology reveal those facts. This kind of discourse reduces his life story to a medical biography. Using his own interpretation of psychoanalytic theory, medicine, and legal concepts, David proposes that Camilo's character is the primary motive behind his crime. His repressions and frustrations make Camilo, at least in David's eyes, a tragedy waiting to happen. According to David Réguel, whose initials are the abbreviation for doctor, Camilo's appearance is timid and lymphatic (Denevi 104). He argues Camilo's weak and sick appearance is a symptom of hidden perversity. David also claims he is the only one capable of analysing Camilo and proving his guilt. He uses science and penal knowledge to examine the case, while the rest of the residents of la Madrileña pity Camilo through the eyes of popular culture and cheap romantic stories.

David also argues Camilo is a neurotic individual with tendencies toward aggression (Denevi 131-132). He is a dangerous individual whose passive personality camouflages his visceral drives. Frustrated and unable to satisfy his desires, Rosaura becomes the perfect prey. For David, Rosaura is a naïve woman who lived her whole live in a mansion. Following the penal code, he argues, Camilo's inappropriate relationship with Rosaura is heinous (Denevi 113). However, as Revel Grove (58-60) illustrates, David's portrayal of Rosaura is actually based on Camilo's tale and his own desires. David quotes psychoanalysis and penal knowledge to understand Camilo and the case, 
reproducing the Western conception of the self, life, and crime.

\section{CONCLUSION}

Marco Denevi's Rosaura a las Diez explores the complexity of social interaction and the way in which individuals imagine the biographies of others using popular culture, law, medicine, psychology, and their own experiences. Foucault and Goffman, among others, acknowledge the importance of literature and often cite novels and stories in their own works. Denevi's novel then promotes a critical analysis of how personal expectations and social institutions shape the way individuals imagine biographies of the self and others. In Denevi's novel, narrators understand the lives of others and themselves through biographical statements related to popular knowledge, medical and psychological theories, and the law. These fields form from the general models a society and its institutions provide to make sense of human life. Visual stigmas and behaviours lead narrators to infer the personality of an individual and imagine their biography. These biographies also shape the way subjects interact with each other. At the same time, these interactions produce looping effects (Hacking 297-298) which reinforce the ideas narrators have about Camilo and Rosaura. The concepts used to explain the protagonist's behaviours are used strategically in reference to the specific discourses that are part of a narrator's worldview. While these discourses may promote different ways of understanding the self, they share a similar vision of adulthood and gender by portraying Camilo, whether to defend or accuse him, as an "hombrecito." Denevi's novel explores the complexity of human experience by providing a socio-psychological examination of the ways Western society constructs the personas of others.

The novel promotes a complex understanding of the production and uses of biographical statements in both anticipating and making social theory. Through Denevi's work, we see how society constructs kinds of beings, biographical statements, and the institutions supporting such sketches of human life. Law, medicine, and everyday life merge within Rosaura a las Diez as fields that provide the general framework that individuals use to make sense of their world. These fields, as Goffman, Foucault, Hacking, and Denevi explore in their works, construct categories of being and their biographies. Both categories of being and biography shape how individuals understand themselves, others, and their interactions. Furthermore, the same discourses individuals use to stigmatise others are internalised by the individuals whose attributes are deemed problematic by social conventions. While we don't usually think of psychology, medicine, and law as fields embedded in the production of biographical statements, Denevi's novel, along with social theory, invites us to look at how biographical statements are constructed and used.

\section{ACKNOWLEDGEMENTS}

I want to express my gratitude to my friend and colleague Ismael Castillo for reading the previous version of this article and providing valuable feedback.

\section{REFERENCES}

Abadie, Nicolás. Marco Denevi en la Década de los Ochenta. Literatura y Política. Literatura y Lingüística, no. 25, 2012, pp. 61-81. http://www.redalyc.org/articulo. oa?id=35223198004. Accessed 1 March 2017.

Álvarez, Jorge W. Inmoralidad de la Prisión Preventiva. Revista De La Facultad De Derecho ( $2^{\circ}$ Época), no. 18, 2000, pp. 199-200, http://revista.fder.edu.uy/index.php/ rfd/article/view/275/298. Accessed 1 March 2017.

Butler, Judith. Giving an Account of Oneself. Fordham University Press, 2005.

Coleman, Alexander. "Four Viewpoints on Murder." The New York Times, 25 October, 1964. pp. 46-47.

Denevi, Marco. Rosaura a las Diez. Centro Editor de América Latina, 1993.

Elms, Alan C. Uncovering Lives: The Uneasy Alliance of Biography and Psychology. Oxford University Press, 1994.

Espada-Brignoni, Teófilo and Frances Ruiz-Alfaro. "Political Repertoires: Tellability and Subjectivation in Gil Scott-Heron." Music as a Platform for Political Communication, edited by Uche Onyebadi, IGI Global 2017, pp. 52-69.

Foucault, Michel. Enfermement, Psychiatrie, Prison. In Dits et Écrits II. Paris: Gallimard, 2001. pp. 322-360.

---------. Discipline and Punish: The Birth of the Prison. Trans. Alan Sheridan. New York: Vintage Books, 1995.

-----------. The Use of Pleasure. Trans. Robert Hurley. New York: Vintage Books, 1990.

-----------. "Prison Talk." In Power/Knowledge: Selected Interview and Other Writings 1972-1977, New York: Pantheon Books, 1980. C. Gordon (Ed.).

------------. The Archeology of Knowledge and the Discourse on Language. Trans. A. M. Sheridan Smith. New York: Vintage Books, 1972.

Goffman, Erving. Stigma: Notes on the Management of Spoiled Identity. Touchstone, 1986.

-----------. The Presentation of the Self in Everyday Life. Anchor Books, 1959.

Hacking, Ian. "Between Michel Foucault and Erving Goffman: Between discourse in the abstract and face to face interaction," Economy and Society, vol. 33, no. 3, 2004, pp. 277-302.

Jansen, I. "Discourse Analysis and Foucault's “Archaeology of Knowledge." International Journal of Caring Sciences, no. 3, 2008, pp. 107-111, http://internationaljournalofcaringsciences.org/docs/Vol1_Issue3_01_Jansen. pdf. Accessed 24 December 2017.

Keller, Evelyn Fox. Lenguaje y Vida: Metáforas de la Biología en el Siglo XX. Manantial, 2000.

Lafforgue, Jorge R., and Rivera, Jorge B. Asesinos de Papel: Ensayos Sobre Narrativa Policial. Colihue, 1996.

Lagmanovich, David. El Microrelato Hispanoamericano. Universidad Pedagógica Nacional, 2007.

Lejeune, Philippe. On Autobiography. Trans. Katherine Leary. University of Minnesota Press, 1989.

Lewald, H. Ernest. "Rosaura a las Diez (Book Review)". Modern Language Journal, vol. 51, no. 2, 1967, p. 128. 
Mattalía, Sonia. La ley y el Crimen: Usos del Relato Policial en la Narrativa Argentina (1880-2000). Iberoamericana, 2008.

Maynes, Mary Jo, Jennifer L. Pierce and Barbara Laslett. Telling Stories: The Use of Personal Narratives in the Social Sciences and History. Cornell University Press, 2008.

Medawar, Peter. The Limits of Science. Oxford University Press, 1984.

Revel Grove, Ivonne. La Realidad Caleidoscópica de la
Obra de Marco Denevi. B. Costa-Amic, 1974.

Swirski, Peter. From Lowbrow to Nobrow. McGill-Queen's University Press, 2007.

Todorov, Tzvetan. "The Typology of Detective Fiction." In The Poetics of Prose. Trans. Richard Howard. Cornell University Press, 1995.

Vezzetti, Hugo. Aventuras de Freud en el País de los Argentinos: De José Ingenieros a Enrique Pichón-Rivière. Paidós, 1996. 